\title{
Effect of Marination Method and Holding Time on Physicochemical and Sensory Characteristics of Broiler Meat
}

\author{
H.G.C.L Gamage ${ }^{1}$, R.K. Mutucumarana ${ }^{1 *}$ and M. S. Andrew ${ }^{2}$ \\ Received: $15^{\text {th }}$ January 2017 / Accepted: $30^{\text {th }}$ June 2017
}

\begin{abstract}
The influence of holding time on the physicochemical and sensory characteristics of broiler meat marinated using three different marination techniques was examined in this study. The experimental design was $4 \times 3$ factorial arrangement of treatments evaluating four marination methods (unmarinated control, injection, immersion and tumbling) and three holding times (4, 8 and $12 \mathrm{~h})$. A total of 84 deboned chicken thigh meat samples (average weight $\pm S D$, $50 \pm 5 \mathrm{~g}$ ) obtained from 32days old broiler chickens was marinated using a commercial marinade mixture and allocated into treatment combinations. Meat samples were analysed for uptake of marinade, $\mathrm{pH}$, water holding capacity (WHC), cooking loss, cooking yield, marinade loss, shearing force value (SFV) and meat colour. Cooked meat samples from marinated treatments were evaluated for sensory properties. Tumbling and injection marination significantly improved $(P<0.05)$ the marinade uptake. Holding marinated meat for $8 \mathrm{~h}$ improved the $\mathrm{pH}(P<0.05)$ and $S F V(P<0.05)$ compared with its unmarinated counterpart. Increasing holding time from 4 to $12 \mathrm{~h}$ had no effect $(P>0.05)$ on $S F V$ of meat marinated by tumbling. Meat held for $12 \mathrm{~h}$ after immersion marination has resulted the highest $(P<0.05)$ marination loss $(8.12 \%)$. In all three marination methods, holding marinated meat for $8 \mathrm{~h}$ increased the $\mathrm{pH}$, WHC and cooking yield and minimized the cooking loss, drip loss and SFV. In tumbling marination, increasing holding time from 4 to $8 \mathrm{~h} \mathrm{had} \mathrm{no} \mathrm{influence}(P>0.05)$ on cooking yield, cooking loss and drip loss. Immersion method significantly increased $(P<0.05)$ the darkness (- $\left.L^{*}\right)$ of chicken thigh meat. Immersion and tumbling methods equally $(P>0.05)$ contributed to the yellowness ( $\left.b^{*}\right)$ of meat. Holding meat for $8 \mathrm{~h}$ after immersion (15.53) and 12 $h$ after tumbling (13.97) significantly $(P<0.05)$ increased the redness $\left(a^{*}\right)$ in chicken thigh. The sensory attributes of the meat samples tended to increase with the increasing holding time $(P<0.05)$ from $4 \mathrm{~h}$ to $8 \mathrm{~h}$. The highest and the lowest score for the overall acceptability were obtained by the meat marinated by the injection and immersion methods, respectively. The present study concluded that holding marinated chicken thigh meat for $8 \mathrm{~h}$ improves $(P<0.05) \mathrm{pH}, \mathrm{WHC}$, cooking yield and meat tenderness and minimizes cooking loss, drip loss and SFV. Chicken thigh meat marinated by immersion method maximally contributes to the development of the physicochemical parameters assessed than tumbling and injection methods. The sensory evaluation suggests that holding injection marinated meat for 8 h attracts consumers the most.
\end{abstract}

Keywords: Holding time, Immersion, Injection, Marination, Thigh meat, Tumbling

\section{INTRODUCTION}

Product diversification is one of the best strategies to establish consumer satisfaction. It also provides a sound platform to face the competition between suppliers. With product diversification, large scale chicken producers tend to produce processed products from fresh broilers. About 70 to $80 \%$ of the total meat products in the current market are further processed using advanced meat processing techniques (Hullberg et al., 2005). Of the various 
further processed meat products, marinated ready-to-cook broiler chicken has become more popular among the consumers (Hullberg et al., 2005).

Marination is a process where the meat is soaked in different marinade solutions containing different concentrations of salt, spices, organic acids, and herbs (Smith and Young, 2007). It is known to improve the meat appearance, product quality, product yield and also the shelf-life of meat (Sheard and Tali, 2004; Latif, 2011). In addition, it enhances the juiciness and tenderness of meat, by increasing the water holding capacity (Alvarado and McKee, 2007).

Effectiveness of the marination process can be affected by several factors such as type of marinade, method of marination, holding time and holding temperature (Fenton et al., 1993; Alvarado and McKee, 2007). Therefore, the overall product quality of the marinated products can be affected by one or more of the aforementioned factors.

The process of marination is more often accomplished by either (i) immersion (ii) injection or (iii) tumbling (Alvarado and McKee, 2007). Immersion involves submerging meat in the marinade solution. It makes marinade solution to be absorbed by the meat through diffusion mechanism. In injection method, the marinade solution is injected into meat using needles or probes allowing the marinade to spread throughout the meat (Alvarado and McKee, 2007). Tumbling marination technique involves rotating meat and falling it in a drum which possesses metal paddles (Kim et al., 2012).

Many studies have been conducted to investigate the influence of type of marinade solutions on the sensory and morphological characteristics of different meat types such as beef (Hinkle, 2010), pork (Sheard and Tali, 2004), chicken (Alvarado and McKee, 2007), and horse meat (Vlahova-Vangelova et al.,
2014). Moreover, some studies investigated the effect of the holding time and temperature on eating qualities of meat (Fenton et al., 1993). A study conducted by Gao et al. (2015) found that different tumbling methods have an effect on meat quality of pork chops. However, the studies conducted to optimize the marination method and the holding time for marinated chicken products are limited. Therefore, the present study was conducted to investigate the effect of three marination methods (immersion, injection and tumbling) and different holding times ( $4 \mathrm{~h}, 8 \mathrm{~h}$ and $12 \mathrm{~h}$ ) on physicochemical and sensory characteristics of broiler meat.

\section{MATERIALS AND METHODS}

\section{Experimental Design}

The experiment design was $4 \times 3$ factorial arrangement of treatments evaluating four marination methods and three holding times. A total of 84 chicken thigh meat samples (average weight $\pm \mathrm{SD}, 50 \pm 5 \mathrm{~g}$ each) was randomly allocated to four treatments namely, un-marinated control, immersion, injection and tumbling. Immediately after marination by either immersion, injection or tumbling the meat samples from each treatment were subdivided $(n=7)$ according to the holding times of $4,8,12$ $\mathrm{h}$ and stored in a refrigerator at $4^{\circ} \mathrm{C}$.

\section{Preparation of Meat Samples}

Fresh deboned thigh meat of broiler chickens (32 days old; average body weight $\pm \mathrm{SD}, 1.5$ $\pm 0.2 \mathrm{~kg}$ ) obtained from a local processing plant was used in this study. External fat, skin and connective tissues associated with thigh meat were manually removed. All the samples were frozen below $-18^{\circ} \mathrm{C}$ for $24 \mathrm{~h}$. The frozen deboned thigh meat was cut into $50 \mathrm{~g}(10 \mathrm{~cm} \mathrm{x} 5 \mathrm{~cm} \mathrm{x}$ $1 \mathrm{~cm})$ pieces. The meat samples were labeled and evaluated for different physicochemical parameters after marination. 


\section{Preparation of Marinade}

A commercially available marinade mixture containing chilli, pepper, garlic, ginger, nutmeg, and salt was dissolved in distilled water and prepared to a solution of a concentration of $20 \%$. The mixture was applied in a ratio of meat: solution of $10: 1(\mathrm{w} / \mathrm{w})$ using one of the marination methods. Injection of marinade to chicken thigh meat samples ( $5 \mathrm{ml}$ to each) was practiced using 18 gauge needles. Tumbling was practiced at $10 \mathrm{rpm}$ for 20 minutes using a tumbling machine (Model No: RGR 150-F, Jaixing Ribon Machine Engineering Co. Ltd. China)

\section{Uptake of Marinade}

Uptake of marinade was determined according to the method described by Fenton et al. (1993) and Klinhom et al. (2015). The excess marinade was removed from the sample surface and the uptake of marinade was calculated by obtaining the difference between weights of the meat sample before and just after marination.

\section{Determination of $\mathrm{pH}$}

The $\mathrm{pH}$ values of the samples were measured using a glass electrode $\mathrm{pH}$ meter (Model HI9125, HANNA instruments, Cluj-Napoca, Romania) as described by Straadt et al. (2007) with slight modifications. Each thigh meat sample $(1 \mathrm{~g})$ was chopped using a mortar and a pestle and was mixed with distilled water at a ratio of 1:5 $(\mathrm{w} / \mathrm{w})$. The prepared mixture was used to measure $\mathrm{pH}$ value.

\section{Marinade Loss}

Marinade loss was calculated as described by Fenton et al. (1993) using the following formula.

Marinade loss $\%=\left[\left(\mathrm{W}_{1}-\mathrm{W}_{2}\right) / \mathrm{W}_{1}\right] \times 100$

Where, $\mathrm{W}_{1}=$ weight after marination $(\mathrm{g})$

$\mathrm{W}_{2}$ =weight of the marinated sample after holding (g)

\section{Cooking Yield}

Cooking yield of marinated thigh meat samples was determined according to the method described by Fenton et al. (1993) using the formula given below. Following to appropriate holding times, marinated thigh meat were cooked in an electric oven (Model UE 800, MEMMERT GmbH + Co. KG, Germany) at $218^{\circ} \mathrm{C}$ to an end point temperature of $75^{\circ} \mathrm{C}$. Each chicken thigh sample was weighed before marination $\left(\mathrm{W}_{1}\right)$ and the weight was taken after cooking $\left(\mathrm{W}_{2}\right)$ to calculate cooking yield.

Cooking yield $\%=\left(\mathrm{W}_{2} / \mathrm{W}_{1}\right) \times 100$

\section{Cooking Loss}

Cooking loss was measured according to the method described by Fenton et al. (1993) with slight modifications. Each treated meat sample was slightly blotted with paper towels, weighed $\left(\mathrm{W}_{1}\right)$ and placed in an electric oven (Model UE 800, MEMMERT GmbH + Co. KG, Germany) at $218^{\circ} \mathrm{C}$. The internal temperature was maintained at $75^{\circ} \mathrm{C}$. The cooked meat samples were blotted and the final weight was recorded $\left(\mathrm{W}_{2}\right)$. Cooking loss was calculated as described by Gao et al. (2015).

Cooking loss $\%=\left[\left(\mathrm{W}_{1}-\mathrm{W}_{2}\right) / \mathrm{W}_{1}\right] \times 100$

\section{Drip Loss}

Drip loss of chicken thigh meat samples was measured using the bag method as described by Otto (2004). After marination, a slice of preweighed (approximately $25 \mathrm{~g}$ ) chicken thigh was hung in a plastic bag and allowed to stand for 2 days at $4^{\circ} \mathrm{C}$. Drip loss was calculated by the weight difference before and after hanging. The drip loss was calculated as percentage drip loss to the initial sample weight.

\section{Shear Force Value}

Tenderness of the cooked meat samples was determined by obtaining Warner Bratzler shearing force values (SFV) using Warner 
Bratzler Meat shearer (Model 240, Instron, USA). Shearing force of $5 \mathrm{~kg}$ of weight in 20 $\mathrm{cm} / \mathrm{min}$ speed was used. The maximum force $(\mathrm{kg})$ required to penetrate the meat was recorded as SFV.

\section{Color Measurement}

Surface meat color in terms of CIE L*, a*, and $b^{*}$ values were measured using a colorimeter (Model CR 10, Konica Minolta, Japan) in which $L^{*}, a^{*}$, and $b^{*}$ values represent the degrees of lightness, redness, and yellowness, respectively.

\section{Sensory Evaluation}

Marinated chicken thigh meat was evaluated for sensory properties by 30 untrained panelists using a pre-designed 6 point hedonic scale. The sensory properties evaluated included toughness, color, aroma, flavor, marinade penetration, and overall acceptability.

Marinated thigh meat samples were ovencooked at $218^{\circ} \mathrm{C}$ until the internal core temperature reached to $75^{\circ} \mathrm{C}$. Meat samples were prepared for presentation by cutting into $2 \mathrm{~cm}$ cubes. The cubes were served to the panelists in white plates to facilitate proper color identification of the samples. Each and every plate was labeled with random numbers and was arranged in a random order for each panelist. The test materials were kept at room temperature of $27^{\circ} \mathrm{C}$. A glass of water was provided to each panelist between two plates to rinse the mouth between the samples.

\section{Data Analysis}

The data were analysed using two-way analysis of variance (ANOVA) using the General Linear Models procedure of SAS (2002). Differences were considered to be significant at $\mathrm{P}<0.05$ and significant differences among treatment means, holding time and their interactions were separated by pdiff option. The data of marinade uptake was analysed using one-way ANOVA. The sensory data were analysed using Friedman test in Minitab 17 software.

\section{RESULTS AND DISCUSSION \\ Effect of Marination Method on Marinade Uptake}

Uptake of marinade in thigh meat samples assessed under different marination methods are shown in Figure 01. There was a significant difference $(\mathrm{P}<0.05)$ in marinade uptake between the treatments. Based on the results chicken thigh meat samples marinated using injection (7.57) and tumbling methods (7.93) resulted a higher $(\mathrm{P}<0.05)$ marination uptake than those marinated using the immersion method (Figure 01).

This finding of the present study is compatible with the findings of Smith and Acton (2001) who described that the injection marinade ensures the regularity of the product without causing losses as seen in immersion. During the process of injection, the marinade is inserted into meat by forcing the marinade penetrating into the meat (Xargayo' et al., 2001). Consequently, a definite quantity of marinade is moved resulting in a higher marinade uptake. In tumbling marination method, massaging effect forces water to move into the muscle (Alvarado and McKee, 2007) causing a higher marinade uptake. Uptake of marinade in immersion method is largely affected by the surface area contact with the marinade and the dipping time (Owens et al., 2009). Hence, this may be the reason for the observed low marinade uptake $(\%)$ obtained in the immersion method. Additionally, the driving force of the marinade into the meat is due mainly to the pressure gradient. When the pressure gradient becomes zero or the surface of the meat is fully saturated with the marinade the uptake of the marinade can be reduced. This fact was previously confirmed with brine marinade, indicating that the higher salt concentration of the brine transfers to the meat until equilibrium is reached between the marinade and meat (Thierry et al., 2011). 


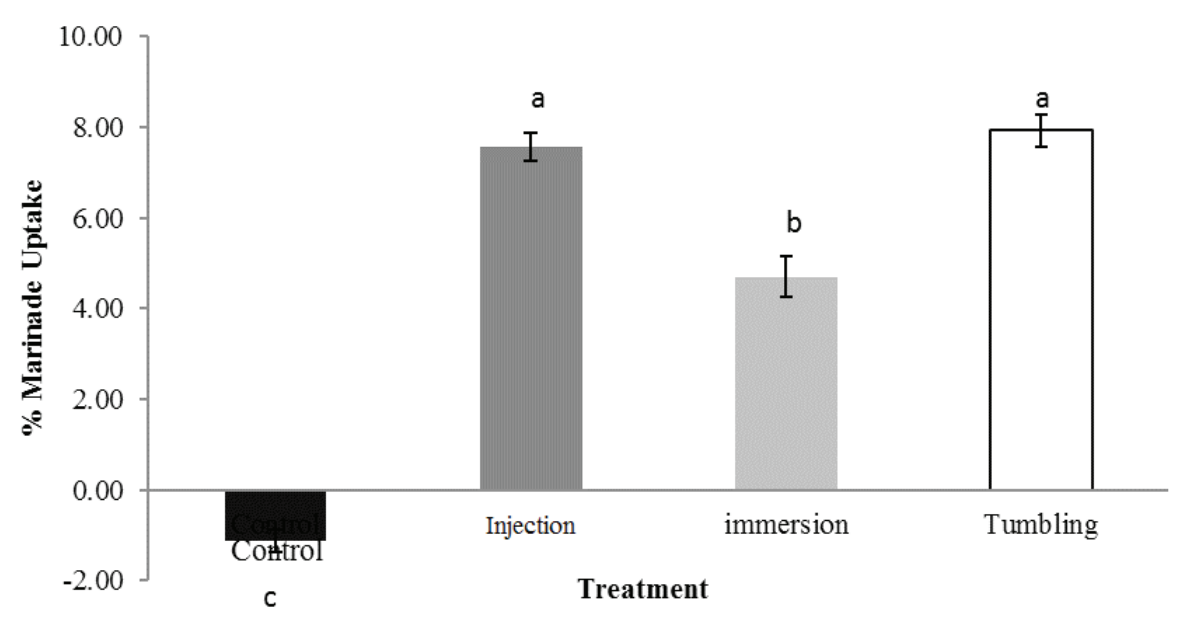

Figure 01: Uptake of marinade in chicken thigh meat samples marinated using different marinating methods.

Effect of Marination Method and Holding Time on Physicochemical Properties of Chicken Thigh Meat

The influence of the marination method on $\mathrm{pH}$ value, marinade loss $(\%)$, cooking yield $(\%)$ and the cooking loss (\%) holding at 4, 8 and 12 hours is summarized in Table 01. A method $x$ holding time interaction $(\mathrm{P}<0.05)$ was observed for the $\mathrm{pH}$ value, marinade loss, cooking yield and cooking loss.

pH Value: Both the marination method $(\mathrm{P}<0.001)$ and holding time $(\mathrm{P}<0.001)$ significantly affected on meat $\mathrm{pH}$. Increasing holding time from 4 to $8 \mathrm{~h}$ increased $(\mathrm{P}<0.05) \mathrm{pH}$ in all treatments. However, increasing the holding time from $8 \mathrm{~h}$ up to $12 \mathrm{~h}$ reduced $(\mathrm{P}<0.05) \mathrm{pH}$ in meat samples subjected to the immersion and injection. Increasing the holding time from $8 \mathrm{~h}$ to $12 \mathrm{~h}$ did not change $(\mathrm{P}>0.05)$ the $\mathrm{pH}$ value in thigh meat samples obtained from the control and marinated using tumbling method resulting a method $\mathrm{x}$ holding time interaction $(\mathrm{P}<0.05)$. In addition to the meat samples marinated using tumbling method at $12 \mathrm{~h}$, the highest $\mathrm{pH}$ value was reported from the meat samples marinated using immersion, injection and tumbling meat samples may be due to the presence of salt and phosphates in the commercial marinade mixture. The finding of the present study is in agreement with those of Cheng and Sun (2008). According to these researchers, the chloride ions of the marinade solution which bind to the protein filaments in muscle fibers in turn increase the ionic charge forming a repulsive force inside of the muscle fibers. This repulsive force is believed to increase the $\mathrm{pH}$ value of meat.

Numerically higher $\mathrm{pH}$ values were observed in thigh meat marinated by tumbling method and it is in agreement with the finding of Gao et al. (2015), who indicated that the tumbling marination stimulates the activity of various proteolytic enzymes. These proteolytic enzymes are known to facilitate the protein degradation of the meat (Lawrie and Ledward, 2006), further increasing the $\mathrm{pH}$ value of muscle protein. Increasing holding time from $4 \mathrm{~h}$ to $12 \mathrm{~h}$, allows more marinade solution to penetrate into the meat resulting increased $\mathrm{pH}$. Similarly, increasing holding time from 4 to 10 $\mathrm{h}$ has increased $\mathrm{pH}$ in pork chops marinated by tumbling (Gao et al., 2015).

methods hold at $8 \mathrm{~h}$. Rise of $\mathrm{pH}$ in marinated 
Table 01: Effect of different marination methods and holding time on physicochemical properties of broiler thigh meat ${ }^{1}$.

\begin{tabular}{|c|c|c|c|c|c|}
\hline & $\begin{array}{l}\text { Holding time } \\
\mathrm{h}\end{array}$ & $\mathrm{pH}$ value & $\begin{array}{c}\text { Marinade loss } \\
\%\end{array}$ & $\begin{array}{c}\text { Cooking yield } \\
\%\end{array}$ & $\begin{array}{c}\text { Cooking loss } \\
\%\end{array}$ \\
\hline \multirow{3}{*}{ Control } & 4 & $6.08^{\mathrm{f}}$ & $0.54^{\mathrm{ef}}$ & $76.96^{\mathrm{bc}}$ & $18.75^{\mathrm{e}}$ \\
\hline & 8 & $6.29^{\mathrm{cd}}$ & $0.56^{\text {ef }}$ & $83.95^{\mathrm{a}}$ & $16.05^{\mathrm{e}}$ \\
\hline & 12 & $6.21^{\mathrm{de}}$ & $5.67^{\mathrm{b}}$ & $67.93^{\text {de }}$ & $32.07^{\mathrm{ab}}$ \\
\hline \multirow{3}{*}{ Immersion } & 4 & $6.23^{\mathrm{de}}$ & $2.50^{\mathrm{c}}$ & $68.83^{\mathrm{de}}$ & $31.17^{\mathrm{ab}}$ \\
\hline & 8 & $6.46^{\mathrm{ab}}$ & $0.89^{\text {def }}$ & $83.75^{\mathrm{a}}$ & $16.25^{\mathrm{e}}$ \\
\hline & 12 & $6.24^{\text {de }}$ & $8.12^{\mathrm{a}}$ & $65.06^{\mathrm{de}}$ & $34.94^{\mathrm{a}}$ \\
\hline \multirow{3}{*}{ Injection } & 4 & $6.17^{\mathrm{ef}}$ & $1.82^{\text {cdef }}$ & $75.32^{\mathrm{c}}$ & $24.68^{\mathrm{cd}}$ \\
\hline & 8 & $6.43^{\mathrm{ab}}$ & $\begin{array}{l}1.02 \\
1.54^{\text {cdef }}\end{array}$ & $83.34^{\mathrm{a}}$ & $16.66^{\mathrm{e}}$ \\
\hline & 12 & $6.25^{\mathrm{de}}$ & $2.29^{\mathrm{cd}}$ & $63.91^{\mathrm{e}}$ & $36.09^{\mathrm{a}}$ \\
\hline \multirow{3}{*}{ Tumbling } & 4 & $6.37^{\mathrm{bc}}$ & $0.43^{\mathrm{f}}$ & $8087^{\mathrm{ab}}$ & $19.12^{\mathrm{de}}$ \\
\hline & 8 & $\begin{array}{l}0.57 \\
6.49^{\mathrm{a}}\end{array}$ & $1.96^{\text {cde }}$ & $\begin{array}{l}80.0 \\
81.46^{\mathrm{ab}}\end{array}$ & $18.54^{\mathrm{e}}$ \\
\hline & 12 & $6.49^{\mathrm{a}}$ & $2.73^{\mathrm{c}}$ & $71.95^{\text {cd }}$ & $28.10^{\mathrm{bc}}$ \\
\hline $\mathrm{SEM}^{2}$ & & 0.033 & 0.531 & 1.93 & 2.02 \\
\hline \multicolumn{6}{|l|}{ Main effects } \\
\hline Method & & & & & \\
\hline Control & & 6.20 & 2.26 & 76.28 & 22.29 \\
\hline Immersion & & 6.31 & 3.84 & 72.54 & 27.46 \\
\hline Injection & & 6.28 & 1.88 & 74.19 & 25.81 \\
\hline Tumbling & & 6.45 & 1.71 & 78.10 & 21.92 \\
\hline $\mathrm{SEM}^{2}$ & & 0.019 & 0.307 & 1.12 & 1.17 \\
\hline \multicolumn{6}{|l|}{ Holding time } \\
\hline $4 \mathrm{~h}$ & & 6.21 & 1.32 & 75.50 & 23.43 \\
\hline $8 \mathrm{~h}$ & & 6.42 & 1.24 & 83.13 & 16.87 \\
\hline $12 \mathrm{~h}$ & & 6.30 & 4.70 & 67.21 & 32.80 \\
\hline $\mathrm{SEM}^{2}$ & & 0.016 & 0.265 & 0.967 & 1.01 \\
\hline \multicolumn{6}{|l|}{ Probabilities, $\mathrm{P}<$} \\
\hline Method & & $* * *$ & $* * *$ & ** & $* *$ \\
\hline Holding time & & $* * *$ & $* * *$ & $* * *$ & $* * *$ \\
\hline Method x Holding time & & $*$ & $* * *$ & $*$ & $* *$ \\
\hline
\end{tabular}

$* \mathrm{P}<0.05 ; * * \mathrm{P}<0.01 ; * * * \mathrm{P}<0.001$.

${ }^{\text {a-f }}$ Means in a column not sharing a common superscript are significantly different $(\mathrm{P}<0.05)$.

${ }^{1}$ Each value represents the mean of seven chicken thigh meat samples.

${ }^{2}$ Pooled standard error of mean.

Marinade loss: Marinade loss was significantly affected by both the marination method $(\mathrm{P}<0.001)$ and the holding time $(\mathrm{P}<0.001)$. The meat samples marinated using immersion method and hold for $12 \mathrm{~h}$ resulted the highest $(\mathrm{P}<0.05)$ marination loss $(8.12 \%)$. However, increasing the holding time from $4 \mathrm{~h}$ to $12 \mathrm{~h}$ did not influence $(\mathrm{P}>0.05)$ on the marinade loss from the meat samples marinated using injection method. Holding meat for $4 \mathrm{~h}$ after marination using tumbling method resulted the numerically minimum marinade loss $(0.43 \%)$ in chicken thighs. The massaging effect occurs during tumbling marination may result the extraction of myofibrillar proteins to the meat surface of the meat improving the proper binding properties (Smith and Acton, 2001). And also the extracted myofibrillar proteins act as a sealer and may facilitate the retention of the marinade (Smith and Acton, 2001). Increased marinade loss with increasing holding time at $12 \mathrm{~h}$ supports to the latest findings of Gao et al. (2015) who indicated that the prolong marination may result the destruction of muscle structure and encourage 
the losses. The puncture holes created during the injection process may facilitate the loss of marinade solution, since they act as channels through which marinade escapes. These results are comparable with the findings of Xargayo' et al. (2001) who described that the immersion results irregular distribution of marinade and the method is not reliable for the industry.

Cooking yield: Cooking yield of the broiler thigh meat was affected by both the marination method $(\mathrm{P}<0.01)$ and the holding time $(\mathrm{P}<0.001)$. In all four treatments holding meat for $8 \mathrm{~h}$ improved the cooking yield and similar to $(\mathrm{P}>0.05)$ the cooking yield obtained after tumbling for $4 \mathrm{~h}$. The cooking yield of thigh meat obtained from the control, injection and immersion methods, first increased and then decreased with the advancing holding time from 4 to $12 \mathrm{~h}$. Absence of this trend in tumbling method resulted a significant method $\mathrm{x}$ holding time interaction effect $(\mathrm{P}<0.05)$ on cooking yield.

Thigh samples marinated using tumbling method resulted comparatively a higher cooking yield. As described by Smith and Acton (2001), this may be due mainly to the massaging effect exert during tumbling which leads to extract the myofibrillar protein into meat surface. Extracted muscle proteins are known to provide two functions; (i) coagulation when the meat is subjected to heat (ii) acting as a sealer when the meat is cooked. Sealing effect facilitates the moisture retention inside of the meat while increasing the cooking yield of the meat (Smith and Acton, 2001).

Cooking loss: Both the marination method $(\mathrm{P}<0.01)$ and the holding time $(\mathrm{P}<0.001)$ had significant effects on the cooking loss of broiler thigh meat. Increasing holding time from $4 \mathrm{~h}$ to $8 \mathrm{~h}$ reduced $(\mathrm{P}<0.05)$ cooking loss from meat marinated by immersion and injection methods. However, broiler thigh meat marinated using tumbling, injection and immersion methods held for $8 \mathrm{~h}$ were similar $(\mathrm{P}>0.05)$ to un-marinated control held for $8 \mathrm{~h}$.

Drip loss: Both the marination method $(\mathrm{P}<0.01)$ and the holding time $(\mathrm{P}<0.001)$ influenced on the drip loss of thigh meat samples tested. There was a significant $(\mathrm{P}<0.001)$ interaction effect between marination method and holding time for drip loss (Table 02). However, the drip loss was not affected $(\mathrm{P}>0.05)$ by increasing the holding time from $4 \mathrm{~h}$ to $8 \mathrm{~h}$ resulting the lowest drip loss in un-marinated thigh meat and the meat marinated by injection and tumbling methods (Table 02). Meat marinated using immersion method also yielded the lowest drip loss $(2.04 \%)$ when held for $8 \mathrm{~h}$. Un-marinated broiler meat held for $12 \mathrm{~h}$ yielded the maximum drip loss $(4.48 \%)$ of the total samples assessed $(\mathrm{P}<0.05)$.

Water holding capacity is another important quality parameter of meat. In most of the studies, WHC is usually expressed as drip loss and cooking loss. Based on the results presented in Table 01 and Table 02 , holding meat from $4 \mathrm{~h}$ and $8 \mathrm{~h}$ in tumbling marination, $8 \mathrm{~h}$ in injection and immersion marination produced the lowest drip loss, lowest cooking loss and the highest cooking yield of chicken thigh meat. These findings are compatible with the findings of Detienne and Wicker (1999) who described that the loosening of microstructures of muscle fibers and increasing the $\mathrm{pH}$ value of the meat with the extraction of myosin, actin, and actomyosin like salt soluble proteins involve in reducing drip loss and cooking loss.

Numbers of researches highlighted that the mechanical tumbling could support the marinade effects and improve the WHC and cooking yield (Alvarado and McKee, 2007). When the holding time increased in tumbling marination from $8 \mathrm{~h}$ to $12 \mathrm{~h}$, cooking loss was increased while the cooking yield of the thigh samples decreased. Numerical increases were observed in the drip loss in tumbling marination when the holding 
Table 02: Effect of marination methods and holding time on the drip loss, shear force value and the colorimetric parameters of broiler thigh meat ${ }^{1}$.

\begin{tabular}{|c|c|c|c|c|c|c|}
\hline & $\begin{array}{l}\text { Holding time } \\
\mathrm{h}\end{array}$ & $\begin{array}{c}\text { Drip } \\
\text { loss, \% }\end{array}$ & $\begin{array}{l}\mathrm{SFV}^{2} \\
(\mathrm{~kg})\end{array}$ & $\begin{array}{c}\text { Darkness, } \\
\text {-L* }\end{array}$ & $\begin{array}{c}\text { Yellowness, } \\
\text { b* }^{*}\end{array}$ & $\begin{array}{c}\text { Redness, } \\
a^{*}\end{array}$ \\
\hline \multirow{3}{*}{ Control } & 4 & $2.06^{\text {cde }}$ & $2.62^{\mathrm{ab}}$ & $41.39^{c}$ & -5.73 & $9.60^{\text {de }}$ \\
\hline & 8 & $1.44^{\mathrm{e}}$ & $2.41^{\mathrm{abc}}$ & $38.74^{\mathrm{d}}$ & -5.39 & $8.63^{\mathrm{e}}$ \\
\hline & 12 & $4.48^{\mathrm{a}}$ & $2.71^{\mathrm{a}}$ & $39.10^{\mathrm{d}}$ & -6.06 & $9.24^{\mathrm{de}}$ \\
\hline \multirow{3}{*}{ Immersion } & 4 & $2.91^{\mathrm{b}}$ & $1.56^{\mathrm{f}}$ & $43.81^{\mathrm{ab}}$ & 2.47 & $9.50^{\text {de }}$ \\
\hline & 8 & $2.04^{\text {cde }}$ & $1.62^{\mathrm{ef}}$ & $45.74^{\mathrm{a}}$ & 3.79 & $15.53^{\mathrm{a}}$ \\
\hline & 12 & $2.96^{\mathrm{b}}$ & $2.29^{\mathrm{bcd}}$ & $45.74^{\mathrm{a}}$ & 2.23 & $12.54^{\mathrm{bc}}$ \\
\hline \multirow{3}{*}{ Injection } & 4 & $2.03^{\text {cde }}$ & $2.17^{\text {cde }}$ & $38.51^{\mathrm{d}}$ & -2.60 & $9.24^{\mathrm{de}}$ \\
\hline & 8 & $1.96^{\mathrm{cde}}$ & $1.90^{\mathrm{ef}}$ & $42.90^{\mathrm{bc}}$ & -2.16 & $9.66^{\mathrm{de}}$ \\
\hline & 12 & $2.57^{\mathrm{bc}}$ & $1.94^{\mathrm{def}}$ & $41.44^{\mathrm{c}}$ & -2.56 & $9.37^{\mathrm{de}}$ \\
\hline \multirow{3}{*}{ Tumbling } & 4 & $1.60^{\circ}$ & $1.56^{\mathrm{f}}$ & $41.57^{\mathrm{c}}$ & 2.77 & $10.49^{\text {cde }}$ \\
\hline & 8 & $1.72^{\mathrm{de}}$ & $1.81^{\mathrm{ef}}$ & $42.99^{\mathrm{bc}}$ & 3.14 & $11.64^{\mathrm{bcd}}$ \\
\hline & 12 & $2.44^{\text {bcd }}$ & $1.92^{\text {def }}$ & $43.50^{\mathrm{bc}}$ & 1.49 & $13.97^{\mathrm{ab}}$ \\
\hline $\mathrm{SEM}^{3}$ & & 0.260 & 0.134 & 0.792 & 0.699 & 0.906 \\
\hline \multicolumn{7}{|l|}{ Main effects } \\
\hline \multicolumn{7}{|l|}{ Method } \\
\hline Control & & 2.66 & 2.58 & 39.74 & $-5.72^{\mathrm{c}}$ & 9.16 \\
\hline Immersion & & 2.64 & 1.82 & 45.10 & $2.83^{\mathrm{a}}$ & 12.52 \\
\hline Injection & & 2.19 & 2.00 & 40.95 & $-2.44^{b}$ & 9.42 \\
\hline Tumbling & & 1.92 & 1.77 & 42.69 & $2.47^{\mathrm{a}}$ & 12.03 \\
\hline $\mathrm{SEM}^{3}$ & & 0.150 & 0.077 & 0.457 & 0.404 & 0.523 \\
\hline \multicolumn{7}{|l|}{ Holding time } \\
\hline $4 \mathrm{~h}$ & & 2.15 & 1.98 & 41.32 & -0.77 & 9.71 \\
\hline $8 \mathrm{~h}$ & & 1.79 & 1.94 & 42.59 & -0.15 & 11.36 \\
\hline $12 \mathrm{~h}$ & & 3.11 & 2.21 & 42.45 & -1.23 & 11.28 \\
\hline $\mathrm{SEM}^{3}$ & & 0.130 & 0.067 & 0.396 & 0.350 & 0.453 \\
\hline \multicolumn{7}{|l|}{ Probabilities, $\mathrm{P}<$} \\
\hline Method & & $* *$ & $* * *$ & $* * *$ & $* * *$ & $* * *$ \\
\hline Holding time & & $* * *$ & $* *$ & 0.052 & NS & $*$ \\
\hline Method x Holding time & & $* * *$ & $*$ & $* *$ & NS & $* *$ \\
\hline
\end{tabular}

NS, not significant; $* \mathrm{P}<0.05 ; * * \mathrm{P}<0.01 ; * * * \mathrm{P}<0.001$.

${ }^{\text {a-e }}$ Means in a column not sharing a common superscript are significantly different $(\mathrm{P}<0.05)$.

${ }^{1}$ Each value represents the mean of seven broiler thigh meat samples.

${ }^{2}$ Shear force value.

${ }^{3}$ Pooled standard error of mean.

time increased from 8 to $12 \mathrm{~h}$. This effect can be due mainly to the excessive destruction of the muscle microstructure due to the biochemical reactions associated with prolong holding time (Gao et al., 2015).

Though a definite quantity of marinade mixture is directly inserted into the meat during injection process, comparatively a lower WHC was observed for thigh meat marinated by injection method than those marinated by tumbling method. Reason for observed low WHC in meat marinated by immersion held for $4 \mathrm{~h}$ and $8 \mathrm{~h}$ is not clear. One possibility is that injection might have resulted in excessive water losses 
due to created holes in the meat surface during the injection process. These holes may act as channels to evaporate water during thermal processing.

Shear force value: There was a significant interaction effect $(\mathrm{P}<0.05)$ on shear force value (SFV). Shear force value was not affected $(\mathrm{P}>0.05)$ by the holding time when the chicken thigh meat were left un-marinated or subjected to tumbling. The highest and the lowest SFV were reported from the control samples and those marinated by tumbling method, respectively. Increasing holding time from 4 to $8 \mathrm{~h}$ in immersion and 8 to $12 \mathrm{~h}$ in injection methods also produced the minimal SFV which were similar $(\mathrm{P}>0.05)$ to the values those reported in tumbling method.

The results of the present study indicated that the process of marination improved the meat quality by decreasing the SFV while enhancing the meat tenderness. The results also highlighted that irrespective of the holding time, the tumbling marination method is more effective in producing more tender meat to fulfill the consumer satisfaction. A similar finding was revealed by several authors (Hullberg et al., 2005; Cheng et al., 2011; Gao et al., 2015). Shear force values resulted from tumbling marination showed close relationships between other parameters tested. Increased $\mathrm{pH}$ values, low cooking loss and low drip loss were found to associate with the resulted low SFV. In tumbling method salt soluble proteins extracted after cooking may lead to formation of gel-rigid microstructures which can retain more water and fat in the meat which in turn lubricates muscle fibers when chewing (Gao et al., 2015). Tumbling of meat is also known to lower the SFV by loosening muscle structures by destructing the connections between myofibrils and collagen (Hayes et al., 2006; Gao et al., 2014).

Darkness: The effects of marination method and holding time on meat color (CIE Lab values) are indicated in Table 2 . There was a significant interaction effect $(\mathrm{P}<0.01)$ on darkness of chicken thigh meat. Darkness value of thigh meat was not affected $(\mathrm{P}>0.05)$ by the holding time when subjected to immersion and tumbling. However, the marination by immersion yielded the maximum darkness $(\mathrm{P}<0.05)$ in chicken thigh meat ranging from 43.81 to 45.74 .

Yellowness: The method of marination influenced the blueness-yellowness of chicken thigh meat examined $(\mathrm{P}<0.001)$. Un-marinated chicken thigh meat poorly developed yellowness than the marinated products. Immersion and tumbling effectively and equally $(\mathrm{P}>0.05)$ contributed in development of yellowness in chicken thigh meat. The main effect of holding time $(\mathrm{P}>0.05)$ and method $\mathrm{x}$ holding time interaction $(\mathrm{P}>0.05)$ were not significant for yellowness of chicken thigh meat.

Redness: There was a significant interaction effect $(\mathrm{P}<0.01)$ for redness of chicken thigh meat. Holding meat at $8 \mathrm{~h}$ after immersion (15.53) and $12 \mathrm{~h}$ after tumbling (13.97) had the maximum redness in chicken thigh. Increasing holding time from $4 \mathrm{~h}$ to $12 \mathrm{~h}$ did not influence $(\mathrm{P}>0.05)$ the redness of meat from the unmarinated control and marinated using injection method and values were similar $(\mathrm{P}>0.05)$. Increasing holding time from $4 \mathrm{~h}(9.50)$ to $8 \mathrm{~h}$ (15.53) improved $(\mathrm{P}<0.05)$ the redness of meat marinated using immersion method. However, further increase of holding time up to $12 \mathrm{~h}$ reduced $(\mathrm{P}<0.05)$ the redness of meat $(12.54)$ subjected to immersion resulting an interaction between the method and the holding time.

The color of the marinated thighs was particularly resulted from the marinade mixture. Of the methods tested, the immersion method was effective in increasing the surface meat color. Saturation of meat surface with the marinade mixture during immersion process may lead to the development of high color intensity which could be easily observed. The lower L*, a*, and $b^{*}$ values resulted from injection method 
was due mainly to direct insertion of marinade mixture inside the thigh meat during injection process.

\section{Evaluation of Organoleptic Properties in Marinated Chicken Thigh Meat}

The variation of sensory properties with the marination method and holding time is shown in Figure 02.

The highest score $(\mathrm{P}<0.05)$ for the toughness was obtained from the marinated thigh meat samples held for $8 \mathrm{~h}$. However, thigh meat held for $4 \mathrm{~h}$ after marination by injection and tumbling methods improved $(\mathrm{P}<0.05)$ the tenderness of meat. Increased toughness in meat when increasing holding time from $4 \mathrm{~h}$ to $8 \mathrm{~h}$ can be explained by the fact that may be due to the disruption of myofibrils as a result of biochemical and physicochemical reactions causing the tenderness of meat to be reduced.

Injecting marinade and holding meat for $4 \mathrm{~h}$ also improved $(\mathrm{P}<0.05)$ the meat flavor. According to the results, this treatment showed a higher marinade uptake and lower marinade loss when assessed for physicochemical parameters. This may be the reason for exhibiting a higher flavor in injection marinated meat than in meat marinated by immersion. According to Sheard and Tali (2004) and Yusop et al. (2010), complicated physico-chemical and biochemical reactions occur during tumbling process enhance the formations of aromatic compounds and flavor substances.

Thigh meat marinated by immersion method improved $(\mathrm{P}<0.05)$ aroma and surface colour when hold the meat for $4 \mathrm{~h}$ and $12 \mathrm{~h}$, respectively. Increased surface colour observed in thighs marinated by immersion method may be mainly due to the saturation of meat surface by the marinade.

Marinade penetration, colour penetration and the overall acceptability were the highest $(\mathrm{P}<0.05)$ in thigh meat hold for $8 \mathrm{~h}$ after injecting marinade into meat. The lowest score $(\mathrm{P}<0.05)$ for the overall acceptability was obtained by the meat marinated by the immersion method. Due to the forcing of marinade solution into the meat during the injection process, the marinade uptake into the meat can be increased. Therefore, the marinade penetration and the color penetration into the meat are higher in injection treated meat.

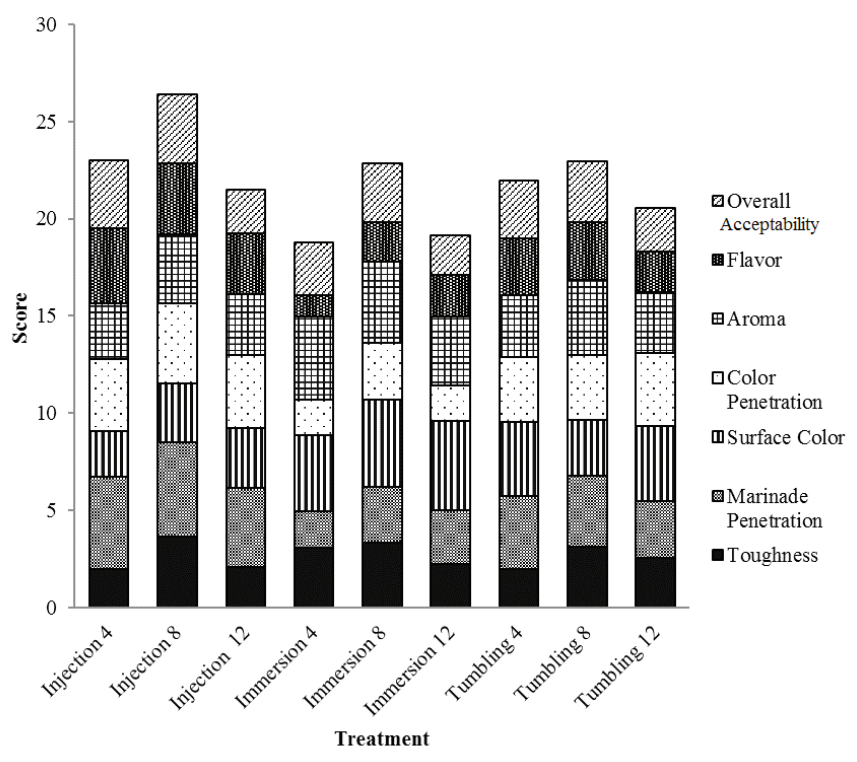

Figure 02: Sensory properties evaluation of thigh meat samples marinated with different marination methods and hold times. 
The results clearly indicated that the sensory attributes of the meat samples were tended to increase with the increasing holding time from $4 \mathrm{~h}$ to $8 \mathrm{~h}$. Increasing the holding time from $8 \mathrm{~h}$ to $12 \mathrm{~h}$ negatively affected on the most of the sensory attributes inclusive of overall acceptability. Prolong holding time is known to cause much more damage to the micro-structure of the meat resulting poor sensory properties. Similar results were observed by Gao et al. (2015), in tumbling method.

\section{CONCLUSION}

It can be concluded that holding marinated chicken thigh meat for $8 \mathrm{~h}$ improves $\mathrm{pH}$, cooking yield and tenderness and minimizes cooking loss, drip loss and shear force value. Holding $8 \mathrm{~h}$ after injecting or immersing marinade into chicken thigh meat minimizes marinade loss. The best marinade uptake can be achieved by marinating meat using tumbling and injection methods. Marination held for $8 \mathrm{~h}$ improves the $\mathrm{pH}$ and tenderness of meat than un-marinated meat. Color attributes of meat can be best achieved by immersion method. In overall, chicken thigh meat marinated by immersion method best contributes to the development of physicochemical parameters than those marinated by tumbling and injection methods. In contrast, the results of the sensory evaluation suggested that the panelists prefer mostly the meat marinated using injection method held for $8 \mathrm{~h}$.

\section{ACKNOWLEDGEMENTS}

Authors wish to appreciate the assistance of the technical staff of the Department of Animal Science, Faculty of Agriculture, University of Peradeniya and Maxies and Company (Pvt.) Ltd, Wennappuwa, Sri Lanka.

\section{REFERENCES}

Alvarado, C.Z. and McKee, S. (2007). Marination to improve functional properties and safety of poultry meat, Journal of Applied Poultry Research. 16:113-120. DOI: http://dx.doi. org/10.1093/japr/16.1.113

Cheng, Q. and Sun, D.W. (2008). Factors affecting the water holding capacity of red meat products: a review of recent research advances, Critical Reviews in Food Science and Nutrition. 48(2): 137-159. DOI: http://dx.doi.org/10.1080/10408390601177647

Cheng, J.H., Wang, S. T., Sun, Y. M. and Ockerman, H.W. (2011). Effect of phosphate, ascorbic acid and $\alpha$-tocopherol injected at one-location with tumbling on quality of roast beef, Meat Science. 87(3): 223-228. DOI: http://dx.doi.org/10.1016/j.meatsci.2010.10.013

Detienne, N. and Wicker, L. (1999). Sodium chloride and tripolyphosphate effects on physical and quality characteristics of injected pork loins, Journal of Food Science. 64(6): 1042-1047. DOI: http://dx.doi.org/10.1111/j.1365-2621.1999.tb12278.x

Fenton, F.L. Hand, L.W. and Berry, J.G. (1993). Effect of marination holding time and temperature on chicken breast halves. Oklahoma Agricultural Experiment Station. Pp 99-94. DOI: http:// dx.doi.org/10.4148/2378-5977.1779

Gao, T., Li, J., Zhang, L., Jiang, Y., Liu, Y., Zhang, X., Gao, F. and Zhou, G. (2015). Effect of different tumbling marination methods and time on the quality characteristics of prepared pork chops, Animal Science. 28(7): 1020-1027. DOI: http://dx.doi.org/10.5713/ajas.14.0918 
Gao, T., Li, J., Zhang, L., Jiang, Y., Song, L., Ma, R., Gao, F. and Zhou, G. (2014). Effect of different tumbling marinade treatments on the water status and protein properties of prepared pork chops, Journal of the Science of Food and Agriculture. 95: 2494-2500. DOI: http:// dx.doi.org/10.1002/jsfa.6980

Hayes, J.E., Desmond, E.M., Troy, D.J., Buckley, D.J. and Mehra, R. (2006). The effect of enhancement with salt, phosphate and milk proteins on the physical and sensory properties of pork loin. Meat Science. 72(3): 380-386. DOI: http://dx.doi.org/10.1016/j. meatsci.2005.05.009

Hinkle, J. B. (2010). Acid marination for tenderness enhancement of beef bottom round. Theses and Dissertations in Animal Science, European Food Research and Technology. University of Nebraska - Lincoln. DOI: http://dx.doi.org/10.2527/1992.70103081x

Hullberg, A., Johansson, L. and Lundström, K. (2005). Effect of tumbling and RN genotype on sensory perception of cured-smoked pork loin, Meat Science. 69: 721-732. DOI: http:// dx.doi.org/10.1016/j.meatsci.2004.07.013

Kim, S., Choi, J., Choi, Y., Kim, H., Ahn, K., Kim, H., Kim, T., Song, D. and Kim, C. (2012). Effects of low-temperature tumbling on the quality characteristics of restructured chicken breast ham, Korean Journal for Food Science of Animal Resources. 32: 268-273. DOI: http:// dx.doi.org/10.5851/kosfa.2012.32.3.268

Klinhom, P., Klinhom, J., Senapa, J. and Methawiwat, S. (2015). Improving the quality of citric acid and calcium chloride marinated culled cow meat, International Food Research Journal. 22(4): 1410-1416. DOI: http://dx.doi.org/10.4028/www.scientific.net/amm.855.70

Latif, S. (2011). Effect of marination on the quality characteristics and microstructure of chicken breast meat cooked by different methods, Seria zootehnie lucrative ştiinţifice. 54: 314-324. DOI: http://dx.doi.org/10.1016/s0309-1740(97)00083-1

Lawrie, R.A. and Ledward, D.A. (2006). The eating quality of meat. In: Lawrie's Meat Science. (Lawrie, R.A. and Ledward, D.A. Eds.). Woodhead Publishing Limited, England. 279-337. DOI: http://dx.doi.org/10.1201/9781439833094

Otto, G., Roehe, R., Looft, H., Thoelking, L. and Kalm, E. (2004). Comparison of different methods for determination of drip loss and their relationships to meat quality and carcass characteristics in pigs, Meat Science. 68: 401-409. DOI: http://dx.doi.org/10.1016/j.meatsci.2004.04.007

Owens, C.M., Alvarado, C. and Sams, A.R. (2009). Poultry Meat Processing, $2^{\text {nd }}$ Edition. Taylor \& Francis, LLC. 454pp. DOI: http://dx.doi.org/10.1201/b15805

SAS Institute (2002) SAS ${ }^{\circledR}$ Qualification Tools User's Guide. Version 9.1.3. SAS Institute Inc., Cary, NC. DOI: http://dx.doi.org/10.1177/0894439314544925

Sheard, P.R. and Tali, A. (2004). Injection of salt, tripolyphosphate and bicarbonate marinade solutions to improve the yield and tenderness of cooked pork loin, Meat Science. 68:305311. DOI: http://dx.doi.org/10.1016/j.meatsci.2004.03.012 
Smith, D.P. and Young, L.L. (2007). Marination pressure and phosphate effects on broiler breast fillet yield, tenderness, and color, Poultry Science. 86:2666-2670. DOI: http://dx.doi. org/10.3382/ps.2007-00144

Smith, D.P. and Acton, J.C. (2001). Marination, cooking, and curing of poultry products. In: Poultry Meat Science. (Sams, A.R. Ed.). CRC Press, Boca Raton, FL. 257-280. DOI: http:// dx.doi.org/10.1201/b15805-16

Thierry, G., Philippe, B., Julien, R., Gilles, T. and Antoine, C. (2011). Swelling and shrinkage regimes during the acidic marination of meat in presence of salt. In: Food Process Engineering in a Changing World. Proceedings of the $11^{\text {th }}$ International Congress on Engineering and Food (ICEF11), (Taoukis Petros, S., Stoforos Nikolaos, G., Karathanos Vaios, T. and Saravacos George, D. Eds.). IAEF, Athens, NTUA.1349-1350. DOI: http://dx.doi.org/10.1007/978-14614-7906-2

Vlahova-Vangelova, D.B., Abjanova, S., Dragoev, S.G. (2014). Influence of the marinating type on the morphological and sensory properties of horse meat, Acta Scientiarum Polonorum Technologia Alimentaria. 13(4): 403-411. DOI: http://dx.doi.org/10.17306/j.afs.2014.4.7

Xargayo', M., Lagares J., Fernandez E., Ruiz, D. and Borrell, D. (2001). Fresh meat spray marinating: The influence of spray injection on the quality of marinated products. http:// en.metalquimia.com/upload/document/article-en-7.pdf . 15.01.2016. DOI: http://dx.doi. org/10.14573/altex.1408191

Yusop, S.M., O’Sullivan, M.G., Kerry, J.F. and Kerry, J.P. (2010). Effect of marinating time and low $\mathrm{pH}$ on marinade performance and sensory acceptability of poultry meat, Meat Science. 85: 657-663. DOI: http://dx.doi.org/10.1016/j.meatsci.2010.03.020 